\title{
Effects of amodiaquine and artesunate on sulphadoxine-pyrimethamine pharmacokinetic parameters in children under five in Mali
}

Mamadou M Tekete ${ }^{1}$, Sékou Toure ${ }^{1}$, Alfia Fredericks², Abdoul H Beavogui ${ }^{1}$, Cheick PO Sangare ${ }^{1}$, Alicia Evans², Peter Smith², Hamma Maiga', Zoumana I Traore', Ogobara K Doumbo', Karen I Barnes² and Abdoulaye A Djimde ${ }^{1 *}$

\begin{abstract}
Background: Sulphadoxine-pyrimethamine, in combination with artesunate or amodiaquine, is recommended for the treatment of uncomplicated malaria and is being evaluated for intermittent preventive treatment. Yet, limited data is available on pharmacokinetic interactions between these drugs.

Methods: In a randomized controlled trial, children aged 6-59 months with uncomplicated falciparum malaria, received either one dose of sulphadoxine-pyrimethamine alone (SP), one dose of SP plus three daily doses of amodiaquine $(\mathrm{SP}+\mathrm{AQ})$ or one dose of SP plus 3 daily doses of artesunate (SP+AS). Exactly $100 \mu \mathrm{l}$ of capillary blood was collected onto filter paper before drug administration at day 0 and at days 1, 3, 7, 14, 21 and 28 after drug administration for analysis of sulphadoxine and pyrimethamine pharmacokinetic parameters.

Results: Fourty, 38 and 31 patients in the SP, SP+AQ and SP+AS arms, respectively were included in this study. The concentrations on day 7 (that are associated with therapeutic efficacy) were similar between the SP, SP+AQ and SP+AS treatment arms for sulphadoxine (median [IQR] 35.25 [27.38-41.70], 34.95 [28.60-40.85] and 33.40 [24.6344.05] $\mathrm{\mu g} / \mathrm{mL}$ ) and for pyrimethamine (56.75 [46.40-92.95], 58.75 [43.60-98.60] and 59.60 [42.45-86.63] ng/mL). There were statistically significant differences between the pyrimethamine volumes of distribution (4.65 [3.93-6.40], 4.00 [3.03-5.43] and 5.60 [4.40-7.20] L/kg; $p=0.001)$ and thus elimination half-life (3.26 [2.74 -3.82], 2.78 [2.24-3.65] and 4.02 [3.05-4.85] days; $p<0.001$ ). This study confirmed the lower SP concentrations previously reported for young children when compared with adult malaria patients.

Conclusion: Despite slight differences in pyrimethamine volumes of distribution and elimination half-life, these data show similar exposure to SP over the critical initial seven days of treatment and support the current use of SP in combination with either AQ or AS for uncomplicated falciparum malaria treatment in young Malian children.
\end{abstract}

Keywords: Pharmacokinetic, Combination therapy, Sulphadoxine, Pyrimethamine, Amodiaquine, Artesunate and Malaria

\footnotetext{
* Correspondence: adjimde@mrtcbko.org

${ }^{1}$ Molecular Epidemiology and Drug Resistance Unit, Malaria Research and Training Centre, Department of Epidemiology of Parasitic Diseases, Faculty of Medicine, Pharmacy and Dentistry, University of Bamako, P.O. Box: 1805,

Bamako, Mali

Full list of author information is available at the end of the article
} 


\section{Background}

Malaria remains a major public health problem, particularly in sub-Saharan Africa, where it claims nearly 750,000 lives of children under the age of five years [1]. To improve cure rates and delay the development and spread of artemisinin resistance, the World Health Organization (WHO) recommends artemisinin-based combination therapy (ACT) [2]. Nearly all malaria endemic countries and territories worldwide have adopted ACT as first-line treatment for Plasmodium falciparum malaria [1]. However, many studies show fewer treatment failures by day 28 when sulphadoxine-pyrimethamine $(\mathrm{SP})$ is combined with amodiaquine $(\mathrm{AQ})$ rather than artesunate (AS) [3-5]. SP monotherapy is the only drug recommended for intermittent preventive treatment during pregnancy (IPTp) and $\mathrm{SP}+\mathrm{AQ}$ is a strong candidate for IPT in infants (IPTi) and in children (IPTc) [4-11].

Resistance to SP is wide spread in Africa, with high level of resistance in east Africa compared to west Africa. That is confirmed by the level of $d h f r$ and $d h p s$ mutation levels, particularly dhps540 which best predicts the in vivo SP resistance [12].

Despite some level of resistance to SP and AQ, the combination of the two drugs is effective on falciparum malaria in much of West Africa.

And, despite these widespread use of SP, the pharmacokinetic parameters of SP when used in combination with AS or AQ is poorly documented, particularly in young children. Altered pharmacokinetic parameters contribute to the increased risk of young children failing SP treatment. After adjusting for dosage, median sulphadoxine and pyrimethamine areas under the concentration time curves in children aged 2-5 years old are approximately half those in adults [13]. This study investigated the effect of combination with either AQ or AS on SP pharmacokinetic parameters in children under-five years of age enrolled in a randomized controlled trial on the treatment of uncomplicated falciparum malaria.

\section{Methods}

\section{Study design}

This was an open label clinical trial using the WHO 2003 protocol [14] conducted in Bancoumana, Mali, during the malaria transmission seasons of 2004 (August 2004-January 2005) and 2005 (July 2005-January 2006). Bancoumana is a rural village of around 12,000 people located 60 kilometers south-west of Bamako. Plasmodium falciparum malaria is both endemic and seasonal with parasitaemia prevalence rates ranging from 40-50\% in the dry season (October-May) and $70-85 \%$ in the rainy season (June-September)[15,16]. Inclusion criteria for this study included 1) parental consent; 2) age between 6 and 59 months; 3) an axillary temperature between $35.5^{\circ} \mathrm{C}$ and $39.5^{\circ} \mathrm{C}$; and 4) P. falciparum monospecific parasitaemia between 2,000 and 200,000 parasites/ul (parasite density was measured by microscopy after staining thick smear with Giemsa). Exclusion criteria included 1) features of severe malaria (haemoglobin $<5 \mathrm{~g} / \mathrm{dL}$; respiratory distress, renal failure; hypoglycaemia, shock; bleeding), 2) danger signs such as prostration, 3) a history of allergy or other severe adverse reaction to the study drugs and 4) more than two episodes of vomiting per day. Children with any of the above exclusion characteristics or who were considered too ill for inclusion in the study, or who declined to participate in the study, received standard and appropriate treatment with chloroquine as then recommended by the National Malaria Control Programme.

Enrolled children were randomized into three treatment arms (SP, $\mathrm{SP}+\mathrm{AQ}$ or $\mathrm{SP}+\mathrm{AS})$ by computer-generated randomization. Directly observed treatment was administered based on weight to the nearest half tablet that would provide the following minimum dose(s): 25 $\mathrm{mg} / \mathrm{kg}$ of sulphadoxine and $1.25 \mathrm{mg} / \mathrm{kg}$ of pyrimethamine as a single dose on day 0 ; with or without AQ 10 $\mathrm{mg} / \mathrm{kg} /$ day over three days or artesunate $4 \mathrm{mg} / \mathrm{kg} /$ day over three days. All subjects were observed for $60 \mathrm{~min}$ utes to monitor for adverse reactions and to make sure that the medicine was not vomited. If vomiting occurred within 30 minutes, the full dose was re-administered. If vomiting occurred between 30 and 60 minutes a halfdose was re-administered. All acute concomitant illnesses were treated for free by the study team, with concomitant medication which had no known SP drug interactions. Parental written informed consent was obtained before any protocol specific procedure was performed. The study was conducted in accordance with the Helsinki Declaration of 1975 (as revised in 1983). The protocol was approved by the ethical committee of the Faculty of Medicine, Pharmacy and Odonto-Stomatology, Bamako, Mali.

\section{Study drugs quality}

Study drugs (Flavoquine ${ }^{\circledR}$ tablet for AQ, Fansidar ${ }^{\circledR}$ tablet for SP and Artesunate tablet for AS)were bought at a private pharmacy in Bamako, Mali. The quality of these drugs were authenticated according to the United States Pharmacopoeia and National Formula (USP-NF) 2004 methods using dissolution testing apparatus in combination with High Performance Liquid Chromatography (17). More than $75 \%$ of the amount of the three drugs (sulphadoxine, pyrimethamine and amodiaquine) of the study were dissolved in the time indicated for each drug. 


\section{Pharmacokinetic sample collection and assay}

Capillary blood samples were collected by fingerprick at day 0 prior to treatment and on days $1,3,7,14,21$ and 28, after SP administration into $1.5 \mathrm{ml}$ Eppendorf tubes without anticoagulant. Exactly $100 \mu \mathrm{l}$ of that blood sample was spotted onto filter paper (Whatman $3 \mathrm{M}$ ), air dried at room temperature and stored in plastic folders with solid desiccant until assayed in March 2008. Concentrations of sulphadoxine and pyrimethamine were determined by a validated method using liquid chromatography-mass spectrometry/mass spectrometry, with the lower limits of quantification set at $10 \mu \mathrm{g} / \mathrm{mL}$ for sulphadoxine and $10 \mathrm{ng} / \mathrm{mL}$ for pyrimethamine. The upper limits of quantification were set at $200 \mu \mathrm{g} / \mathrm{mL}$ for sulphadoxine and $1 \mu \mathrm{g} / \mathrm{mL}$ for pyrimethamine. The coefficient of variation for sulphadoxine was $10.3 \%$ at 65 $\mu \mathrm{g} / \mathrm{mL}$, and pyrimethamine had a coefficient of variation of $13.8 \%$ at165 $\mathrm{ng} / \mathrm{mL}$ as previously described [13].

\section{Pharmacokinetic analysis}

The area under the capillary blood concentration-time curve to infinity (AUC), terminal elimination half-life $(\mathrm{t} 1 / 2)$, apparent volume of distribution (VD) and apparent clearance $(\mathrm{Cl})$ of pyrimethamine and sulphadoxine were determined using a non compartmental model in WinNonLin Professional 3.3 (Pharsight). As there was no intravenous comparator arm in this study, equivalent bioavailability was assumed for comparisons of apparent volumes of distribution and clearance, which were expressed as $\mathrm{Vd} / \mathrm{f}$ and $\mathrm{Cl} / \mathrm{f}$, where $\mathrm{f}$ is the fraction of drug absorbed (unknown).

\section{Statistical analysis}

As most pharmacokinetic parameters were not normally distributed, these were summarized using medians and inter-quartile ranges and compared between the three treatment arms using the Kruskal-Wallis equality-ofpopulations rank test. Categorical data were compared using the Chi-squared test.

\section{Results}

\section{Study population characteristics}

Between 2004 and 2006, we conducted a clinical trial comparing the therapeutic efficacy of SP, SP+AQ and SP+AS. A total of 455 children were included and 441 (97\%) were successfully followed for 28 days. The baseline characteristics in the three treatment arms were comparable for mean age, mean weight and gender $(\mathrm{P}>$ 0.05). Without PCR correction the 28-day uncorrected adequate clinical and parasitological response (ACPR) rates were above $95 \%$ for each of the treatment arms. Early treatment failure (ETF) was only found in the SPmonotherapy arm in three patients $(2 \%, \mathrm{n}=147)$. After
PCR correction by $m s p 2$, the ACPR rates were above $97 \%$ in all three groups.

Among the study population children with complete pharmacokinetic samples from day 0 to day 28 were included in this pharmacokinetic analysis i.e. 41 children in $\mathrm{SP}$ arm, 40 in $\mathrm{SP}+\mathrm{AQ}$ and 33 in $\mathrm{SP}+\mathrm{AS}$. The ages of the children enrolled ranged between 10 and 60 months. Treatment groups were well matched for the baseline characteristics of age, gender, weight, SP $\mathrm{mg} / \mathrm{kg}$ dosage, temperature and hemoglobin (Table 1). Three patients who vomited within 60 minutes (one in each treatment arm), and one patient with quantifiable SP concentrations pre-treatment (day 0 ) and one patient $(S P+A Q$ arm) in whom SP concentrations were below the limits of quantification throughout the follow up period were excluded from the analysis of pharmacokinetic parameters. This analysis was performed on a total of 40, 38 and 31 patients respectively in the SP, SP+AQ and SP $+\mathrm{AS}$ arms (Figure 1).

\section{Pharmacokinetic analysis}

The three treatment arms had similar mean concentration time profiles of sulphadoxine (Figure 2) and pyrimethamine (Figure 3) with almost all children reaching the maximum concentration on Day 1 (103/109 (95\%) for sulphadoxine and 107/109 (99\%) for pyrimethamine. For sulphadoxine, the day 1, 3, and 7 concentrations as well as the AUC, apparent volume of distribution, apparent clearance and elimination half-life were similar between the three treatments arms $(\mathrm{P}>0.05)$ (Table 2). For pyrimethamine, the day 1,3 , and 7 concentrations as well as the AUC and apparent clearance were similar. However, the apparent volume of distribution of pyrimethamine was lower in the $\mathrm{SP}+\mathrm{AQ}$ arm when compared to SP monotherapy $(\mathrm{p}=0.008)$ and SP+AS $(\mathrm{p}<$ 0.001 ) treatment arms. As a consequence the elimination half-life was lower in patients treated with $\mathrm{SP}+\mathrm{AQ}$

Table 1 Baseline characteristics [median (IQR)] by treatment group

\begin{tabular}{lcccc}
\hline & $\begin{array}{c}\text { SP arm } \\
(\mathbf{n}=\mathbf{4 1})\end{array}$ & $\begin{array}{c}\text { SP+AQ arm } \\
(\mathbf{n}=\mathbf{4 0})\end{array}$ & $\begin{array}{c}\text { SP+AS arm } \\
(\mathbf{n}=\mathbf{3 3})\end{array}$ & P-value \\
\hline Age (months) & 48 & 48 & 48 & 0.66 \\
& $(24-48)$ & $(24-48)$ & $(24-48)$ & \\
Gender Male & $21 / 41$ & $23 / 40$ & $19 / 33$ & 0.81 \\
$\mathrm{n}(\%)$ & $(51 \%)$ & $(58 \%)$ & $(58 \%)$ & (Chi-squared) \\
Weight (kg) & 14 & 13.5 & 13 & 0.93 \\
& $(11-16)$ & $(12-16)$ & $(11-15)$ & \\
Temperature & 38.5 & 38.7 & 38.2 & 0.50 \\
(Celcius) & $(38.0-38.9)$ & $(38.1-39.1)$ & $(37.8-39.0)$ & \\
Haemoglobin & 10.7 & 10.3 & 10.9 & 0.95 \\
(g/dL) & $(9.5-11.8)$ & $(9.4-12.20$ & $(8.9-11.7)$ & \\
\hline
\end{tabular}




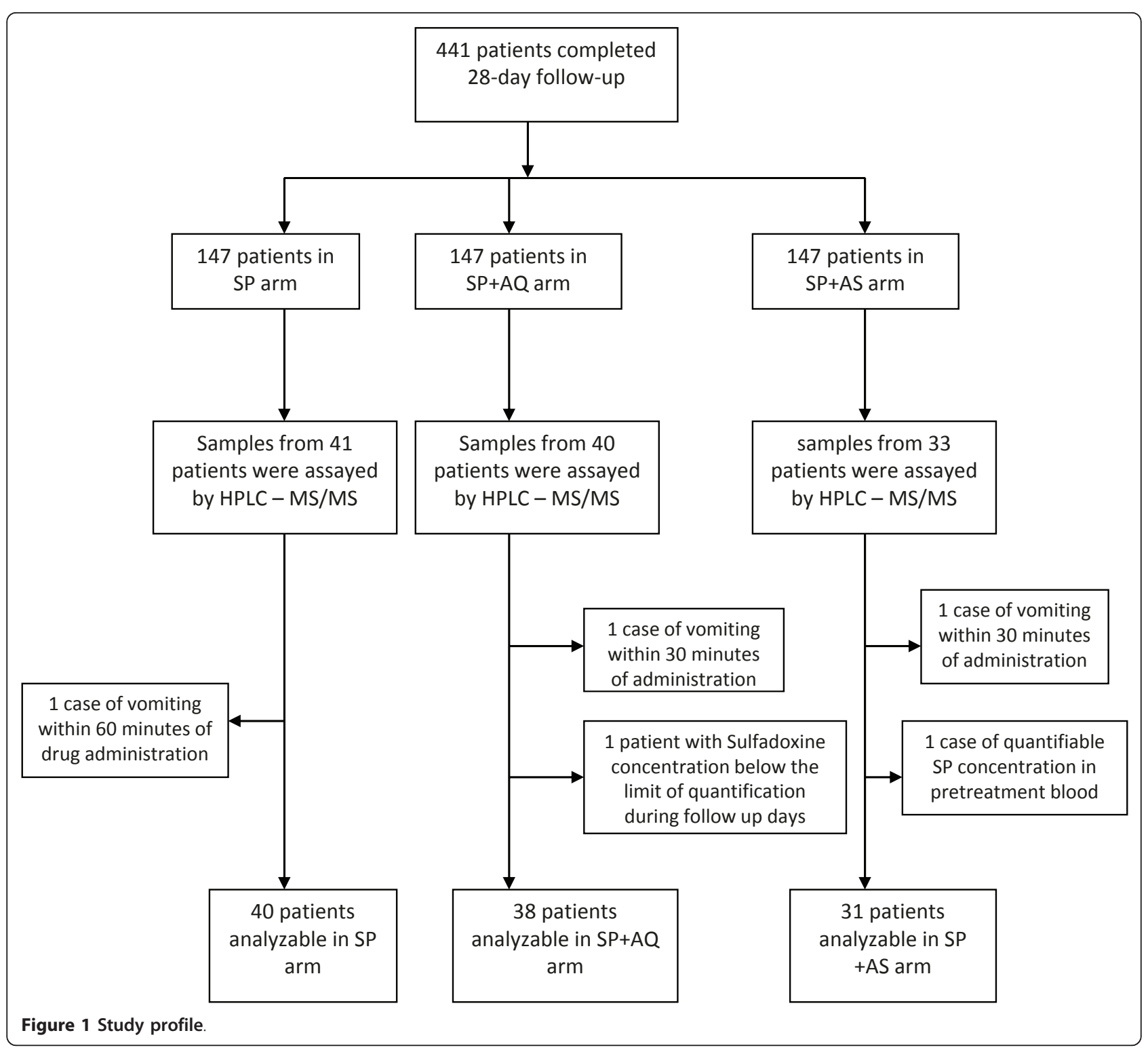

than SP monotherapy $(\mathrm{p}=0.046)$ or SP+AS $(\mathrm{p}=0.001)$. The apparent Volume of distribution for pyrimethamine was also lower following SP monotherapy than SP+AS $(\mathrm{p}=0.030)$ (Table 3).

As previously reported this study showed relatively wide inter-individual variation with Coefficients of variation of $29.8 \%$ and $48.7 \%$ for Day-7 concentrations of sulphadoxine and pyrimethamine, respectively.

The child who was retreated with a half-dose following vomiting between 30 and 60 minutes had SP concentrations similar to the medians on day $1(77.7 \mu \mathrm{g} / \mathrm{ml}$ for sulphadoxine and $234 \mathrm{ng} / \mathrm{ml}$ for pyrimethamine). The two children retreated with the full dose for vomiting within 30 minutes had SP concentrations on day 1 that were almost double the median (133 and $137 \mu \mathrm{g} / \mathrm{ml}$ for sulphadoxine and 513 and $661 \mathrm{ng} / \mathrm{ml}$ for pyrimethamine). There were no serious adverse events during this study.

\section{Discussion}

This study reports on SP pharmacokinetic parameters in young African children with uncomplicated P. falciparum malaria in the context of combination therapies, and confirmed the lower SP concentrations previously reported for this age group when compared with adult malaria patients [13]. There was no statistically significant difference between sulphadoxine and pyrimethamine concentrations (at day 1, day 3 and day 7), AUC and elimination half-life between the SP monotherapy and $\mathrm{SP}+\mathrm{AS}$ arms. AS having no impact on these SP 


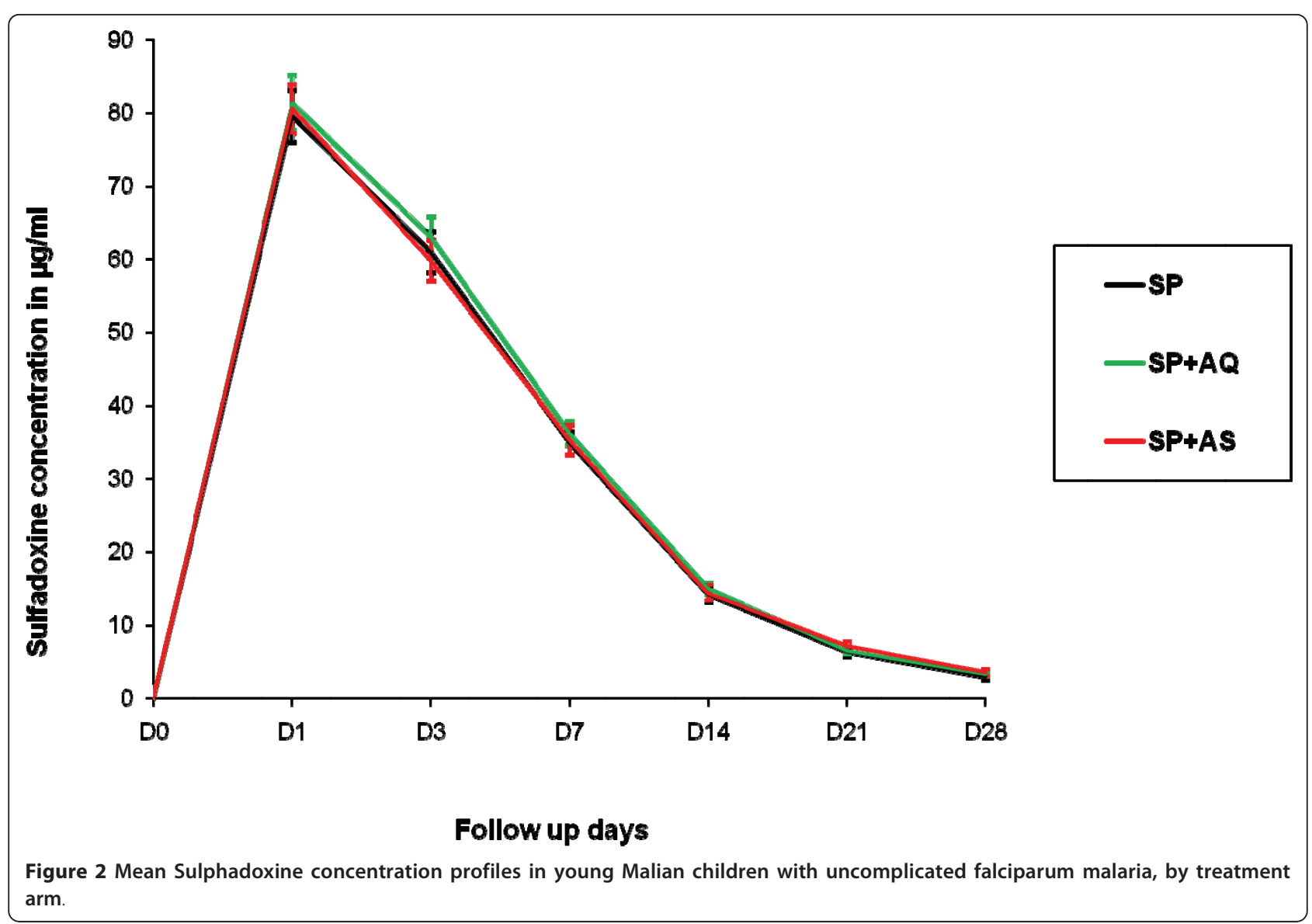

pharmacokinetic parameters is consistent with a study previously reported in healthy adults when AS was administered concomitantly with SP [18] and is reassuring, supporting the use of AS in combination with SP. However, a higher volume of distribution of pyrimethamine in the SP + AS arm when compared to SP monotherapy arm was observed in this study [median 5.60 vs. $4.65 \mathrm{~L} / \mathrm{kg} ; \mathrm{p}=0.030$ (Table 3)].

Although adding amodiaquine to SP had no effect on sulphadoxine pharmacokinetic parameters, a significant decrease in the apparent volume of distribution and elimination half-life of pyrimethamine in the SP+AQ arm was observed. However, this did not result in a significant change in pyrimethamine concentrations in the blood in $\mathrm{SP}+\mathrm{AQ}$ arm over the critical initial seven days of treatment nor the AUC. The absence of a substantial $\mathrm{PK}$ interaction in our study population supports the effectiveness of SP+AQ in IPTc $[7,10]$ and in uncomplicated falciparum malaria treatment in children under five [5]. The effect of the shorter pyrimethamine elimination half-life could possibly reduce the post-treatment prophylactic effect of sulphadoxine-pyrimethamine plus amodiaquine as resistance to these partner drugs increases.
Day-7 concentrations of sulphadoxine and pyrimethamine are a good surrogate measure of their respective total whole blood AUCs [13] and Day 7 concentration is a predictor of treatment outcome [19]. Day7 pyrimethamine concentration observed in this study was slightly higher in $\mathrm{SP}+\mathrm{AQ}$ arm, but this difference was not statistically significant (Figure 3). When compared with SP Day-7 capillary blood concentrations previously published for children aged 2-5 years in southern Africa [sulphadoxine median 31.3 (IQR 19.7-52.0); pyrimethamine median 70.3 (IQR 39.0-101.9)],[13] day-7 concentrations in young Malian children were similar for sulphadoxine, but appeared lower for pyrimethamine.

The vast majority of our patients achieved maximum concentrations of both sulphadoxine and pyrimethamine on day 1 . However, the exact Cmax and Tmax could not be determined precisely because of limited sampling frequency. The concentration of artesunate could not be quantified because of the sampling methodology used, and the concentrations and pharmacokinetic parameters of amodiaquine (when administered with SP) will be reported separately.

The two children who were retreated with the full dose after vomiting within 30 minutes of SP 


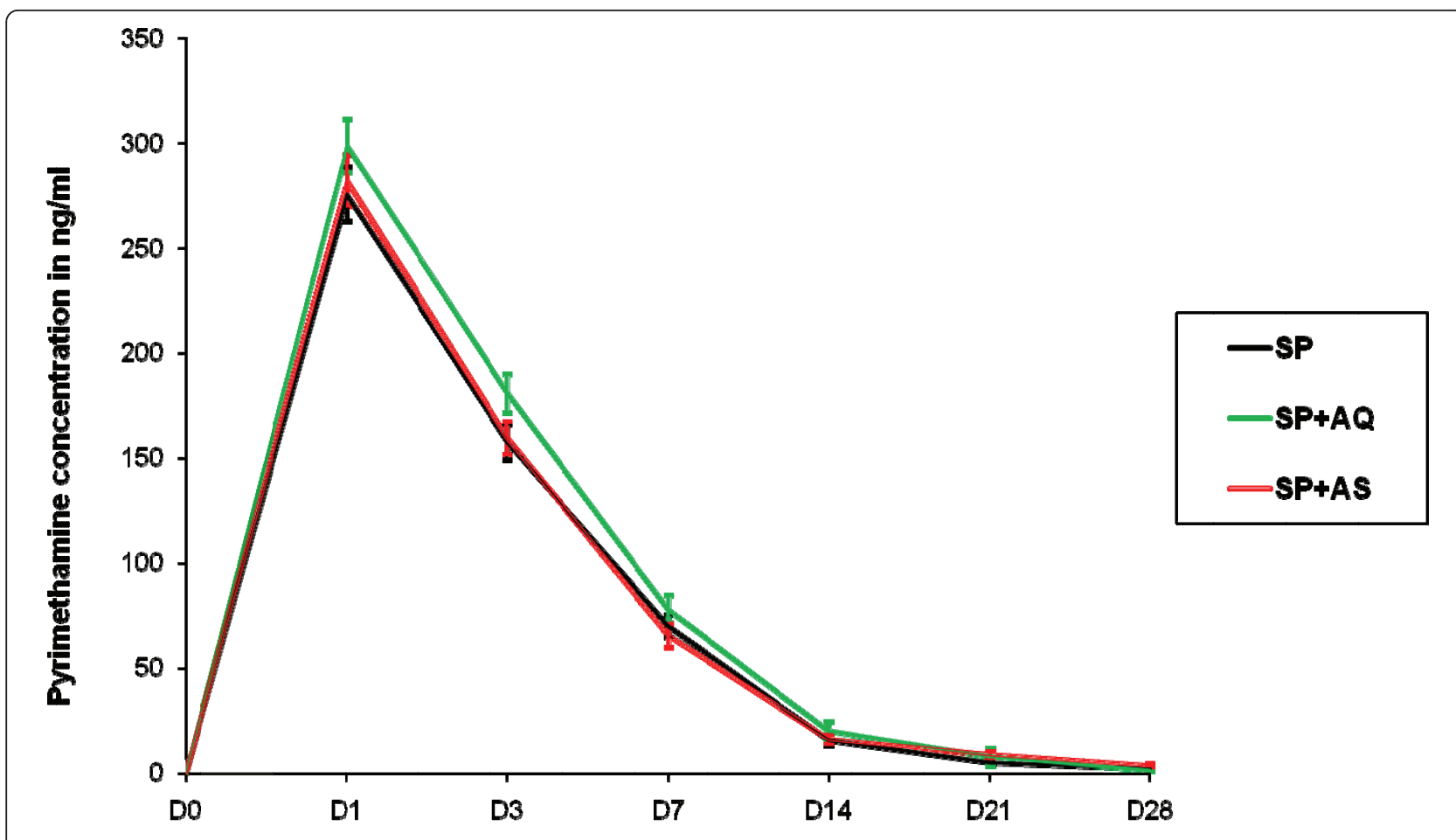

Follow up days

Figure 3 Mean Pyrimethamine concentration profiles in young Malian children with uncomplicated falciparum malaria, by treatment arm.

administration had approximately double the median SP concentrations on day 1 , suggesting that further data is needed to inform optimal dosing in patients with early vomiting.
In this study conducted in Mali in 2004-2006, SP or its combination with AS or AQ remained highly effective with more than a $95 \%$ adequate clinical and parasitological response rate. Although this level of efficacy

Table 2 Sulphadoxine pharmacokinetic parameters (Median [IQR]) in Malian children under five with uncomplicated falciparum malaria, by treatment group

\begin{tabular}{|c|c|c|c|c|}
\hline PARAMETERS & SP arm & $\mathrm{SP}+\mathrm{AQ}$ arm & $\mathrm{SP}+\mathrm{AS}$ arm & $\begin{array}{c}\text { P-value } \\
\text { [Kruskal-Wallis] }\end{array}$ \\
\hline Sulphadoxine dose (mg/kg) & $\begin{array}{c}27.8 \\
(25.0-27.8)\end{array}$ & $\begin{array}{c}28.8 \\
(25-31.3)\end{array}$ & $\begin{array}{c}27.8 \\
(25-28.8)\end{array}$ & 0.46 \\
\hline $\begin{array}{c}\text { Median Concentration day } 1 \\
{[\mathrm{IQR}](\mu \mathrm{g} / \mathrm{mL})}\end{array}$ & $\begin{array}{c}73.20 \\
{[66.55-89.33]}\end{array}$ & $\begin{array}{c}80.95 \\
{[65.05-89.08]}\end{array}$ & $\begin{array}{c}76.80 \\
{[62.70-93.50]}\end{array}$ & 0.86 \\
\hline $\begin{array}{c}\text { Median Concentration day } 3 \\
{[\mathrm{IQR}](\mu \mathrm{g} / \mathrm{mL})}\end{array}$ & $\begin{array}{c}61.3 \\
{[47.8-73.0]}\end{array}$ & $\begin{array}{c}63.9 \\
{[49.6-72.7]}\end{array}$ & $\begin{array}{c}57.9 \\
{[47.4-69.8]}\end{array}$ & 0.71 \\
\hline $\begin{array}{c}\text { Median Concentration day } 7 \\
{[\mathrm{IQR}](\mu \mathrm{g} / \mathrm{mL})}\end{array}$ & $\begin{array}{c}35.25 \\
{[27.38-41.70]}\end{array}$ & $\begin{array}{c}34.95 \\
{[28.60-40.85]}\end{array}$ & $\begin{array}{c}33.40 \\
{[24.63-44.05]}\end{array}$ & 0.97 \\
\hline $\begin{array}{c}\text { Median AUC [IQR] } \\
(\mu \mathrm{g} / \mathrm{mL} . \text { day })\end{array}$ & $\begin{array}{c}660.08 \\
{[520.37-832.11]}\end{array}$ & $\begin{array}{c}682.67 \\
{[579.45-797.12]}\end{array}$ & $\begin{array}{c}672.04 \\
{[525.35-898.86]}\end{array}$ & 0.88 \\
\hline $\begin{array}{c}\text { Median VD [IQR] } \\
(\mathrm{mL} / \mathrm{kg})\end{array}$ & $\begin{array}{c}349.35 \\
{[295.43-434.25]}\end{array}$ & $\begin{array}{c}345.60 \\
{[294.15-427.95]}\end{array}$ & $\begin{array}{c}357.80 \\
{[266.70-427.40]}\end{array}$ & 0.97 \\
\hline $\begin{array}{c}\text { Median T1/2 [IQR] } \\
\text { (days) }\end{array}$ & $5.60[4.62-6.78]$ & $5.77[5.11-6.45]$ & $6.13[4.90-7.26]$ & 0.56 \\
\hline Median Clearance [IQR] (mL/kg/day) & $\begin{array}{c}41.85 \\
{[35.13-54.78]}\end{array}$ & $\begin{array}{c}41.65 \\
{[34.20-52.83]}\end{array}$ & $\begin{array}{c}41.00 \\
{[32.10-53.40]}\end{array}$ & 0.80 \\
\hline
\end{tabular}


Table 3 Pyrimethamine pharmacokinetic parameters (Median [IQR]) in Malian children under five with uncomplicated falciparum malaria, by treatment group

\begin{tabular}{|c|c|c|c|c|}
\hline PARAMETERS & SP arm & $\mathrm{SP}+\mathrm{AQ}$ arm & $\mathrm{SP}+\mathrm{AS}$ arm & $\begin{array}{c}\text { P-value } \\
\text { [Kruskal-Wallis] }\end{array}$ \\
\hline Pyrimethamine dose (mg/kg) & $\begin{array}{c}1.39 \\
(1.25-1.56)\end{array}$ & $\begin{array}{c}1.44 \\
(1.25-1.56)\end{array}$ & $\begin{array}{c}1.39 \\
(1.25-1.44)\end{array}$ & 0.46 \\
\hline $\begin{array}{c}\text { Median Concentration day } 1 \\
\text { [IQR] }(\mathrm{ng} / \mathrm{mL})\end{array}$ & $\begin{array}{c}259.50 \\
{[212.50-337.50]}\end{array}$ & $\begin{array}{c}300.50 \\
{[220.00-339.25]}\end{array}$ & $\begin{array}{c}274.00 \\
{[235.00-312.00]}\end{array}$ & 0.55 \\
\hline $\begin{array}{c}\text { Median Concentration day } 3 \\
\text { [IQR] }(\mathrm{ng} / \mathrm{mL})\end{array}$ & $\begin{array}{c}155 \\
{[127-187]}\end{array}$ & $\begin{array}{c}174 \\
{[132-215]}\end{array}$ & $\begin{array}{c}158 \\
{[119-191]}\end{array}$ & 0.14 \\
\hline $\begin{array}{c}\text { Median Concentration day } 7 \\
\text { [IQR] }(\mathrm{ng} / \mathrm{mL})\end{array}$ & $\begin{array}{c}56.75 \\
{[46.40-92.95]}\end{array}$ & $\begin{array}{c}58.75 \\
{[43.60-98.60]}\end{array}$ & $\begin{array}{c}59.60 \\
{[42.45-86.63]}\end{array}$ & 0.85 \\
\hline $\begin{array}{l}\text { Median AUC } \\
\text { [IQR] (ng/mL.day) }\end{array}$ & $\begin{array}{c}1307.45 \\
{[1087.59-1773.94]}\end{array}$ & $\begin{array}{c}1405.32 \\
{[1110.36-2016.49]}\end{array}$ & $\begin{array}{c}1363.76 \\
{[1193.71-1765.91]}\end{array}$ & 0.46 \\
\hline $\begin{array}{l}\text { Median VD }[\mathrm{IQR}] \\
(\mathrm{L} / \mathrm{kg})\end{array}$ & $\begin{array}{c}4.65 \\
{[3.93-6.40]}\end{array}$ & $\begin{array}{c}4.00 \\
{[3.03-5.43]}\end{array}$ & $\begin{array}{c}5.60 \\
{[4.40-7.20]}\end{array}$ & 0.001 \\
\hline $\begin{array}{l}\text { Median T1/2 }[\mathrm{IQR}] \\
\text { (days) }\end{array}$ & $\begin{array}{c}3.26 \\
{[2.74-3.82]}\end{array}$ & $\begin{array}{c}2.78 \\
{[2.24-3.65]}\end{array}$ & $\begin{array}{c}4.02 \\
{[3.05-4.85]}\end{array}$ & 0.0016 \\
\hline Median Clearance [IQR] (L/kg/day) & $\begin{array}{c}1.10 \\
{[0.80-1.38]}\end{array}$ & $\begin{array}{c}1.00 \\
{[0.70-1.30]}\end{array}$ & $\begin{array}{c}1.00 \\
{[0.80-1.20]}\end{array}$ & 0.38 \\
\hline
\end{tabular}

For VD: SP VS. SP $+\mathrm{AQ}, P=0.008 ; \mathrm{SP}+\mathrm{AQ}$ VS. SP $+\mathrm{AS}, P=0.000$; and SP VS. SP $+\mathrm{AS}, P=0.030$

For T1/2: SP VS. $\mathrm{SP}+\mathrm{AQ}, P=0.046 ; \mathrm{SP}+\mathrm{AQ}$ VS. $\mathrm{SP}+\mathrm{AS}, P=0.001$; and $\mathrm{SP} V \mathrm{~S} . \mathrm{SP}+\mathrm{AS}, P=0.071$

of SP when administered alone or in combination with either AS or AQ is quite high in comparison with data from Eastern or Southern Africa [20,21], these rates are common in West Africa [22-24] and may reflect the lower frequency of dihydrofolate reductase (dhfr) and dihydropteroate synthetase (dhps) mutations associated with SP resistance $[25,26]$. Probably because of their strong synergy, the minimum effective concentrations (MEC) of sulphadoxine and/or pyrimethamine have not been clearly defined. In Gabon, where the prevalence of DHFR triple mutation was $\sim 70 \%$, day 3 concentrations associated with treatment success were $100 \mu \mathrm{g} / \mathrm{mL}$ for sulphadoxine and $175 \mathrm{ng} / \mathrm{mL}$ pyrimethamine [27]. Of the 109 children in this study, only $4(3.7 \%)$ and $40(36.7 \%)$ achieved these 'therapeutic' day-three concentrations of sulphadoxine and pyrimethamine, respectively. This might suggest that as dhfr/dhps mutations accumulate the SP concentrations achieved may be insufficient to ensure an adequate clinical and parasitological response rate as recently described in Malawi [28].

\section{Conclusion}

This pharmacokinetic data supports the current use of SP in combination with AS to treat young Malian children with uncomplicated falciparum malaria, and the use of SP + AQ for IPTc. Ongoing monitoring is essential, particularly given the lower pyrimethamine concentrations and the accumulation of $d h f r$ and $d h p s$ mutations that typically occurs in areas with large-scale deployment of SP.

\section{Acknowledgements}

We thank all the patients, parents and guardians of the children who participated in these studies and the many people who assisted with this project, community leaders and health centre staff who participated in the study. This work was supported by the MIM/TDR 2003 (Multilateral Initiative of Malaria/Tropical Disease Research, Grant \#A20238\#), International Atomic Energy Agency RAF/6/025, and by the Malaria Research and Training Centre of the University of Bamako on behalf of the Government of Mali

\section{Author details}

${ }^{1}$ Molecular Epidemiology and Drug Resistance Unit, Malaria Research and Training Centre, Department of Epidemiology of Parasitic Diseases, Faculty of Medicine, Pharmacy and Dentistry, University of Bamako, P.O. Box: 1805, Bamako, Mali. ²Division of Clinical Pharmacology, Department of Medicine, University of Cape Town, Cape Town, South Africa.

\section{Authors' contributions}

MMT contributed to the study design, field studies, pharmacokinetic analyses, data analysis and drafted the manuscript. AHB, CPOS, HM and ZIT, conducted the field studies, collected the samples, and assisted with manuscript preparation. PS, AF and AE developed and or conducted pharmacokinetic assay. KIB contributed to data analysis and manuscript writing. OKD contributed to study design and manuscript writing. AD contributed to the design of the study, oversaw the field and laboratory studies, and to the writing and final approval of the manuscript. All authors read and approved the final manuscript.

\section{Conflict of interest}

The authors declare that they have no competing interests.

Received: 28 June 2011 Accepted: 21 September 2011 Published: 21 September 2011

\section{References}

1. World Health Organization: World malaria report 2008. "WHO/HTM/GMP/ 2008.1" 2008 [http://www.who.int/malaria/wmr2008/malaria2008.pdf], Ref Type: Report.

2. World Health Organization: WHO guidelines for the treatment of malaria. WHO/HTM/MAL/2006.1108 2006 [http://www.who.int/malaria/docs/ TreatmentGuidelines2006.pdf], Ref Type: Report. 
3. Bukirwa $\mathrm{H}$, Critchley J: Sulfadoxine-pyrimethamine plus artesunate versus sulfadoxine-pyrimethamine plus amodiaquine for treating uncomplicated malaria. Cochrane Database Syst Rev 2006, 1:CD004966.

4. Mutabingwa TK, Muze K, Ord R, Briceno M, Greenwood BM, Drakeley C, Whitty CJ: Randomized trial of artesunate+amodiaquine, sulfadoxinepyrimethamine+amodiaquine, chlorproguanal-dapsone and SP for malaria in pregnancy in Tanzania. PLOS ONE 2009, 4:e5138.

5. Kayentao K, Maiga H, Newman RD, McMorrow ML, Hoppe A, Yattara O, Traore $H$, Kone Y, Guirou EA, Saye R, Traore B, Djimde A, Doumbo OK: Artemisinin-based combinations versus amodiaquine plus sulphadoxinepyrimethamine for the treatment of uncomplicated malaria in Faladje, Mali. Malar J 2009, 8:5.

6. Clerk CA, Bruce J, Affipunguh PK, Mensah N, Hodgson A, Greenwood B, Chandramohan D: A randomized, controlled trial of intermittent preventive treatment with sulfadoxine-pyrimethamine, amodiaquine, or the combination in pregnant women in Ghana. J Infect Dis 2008, 198:1202-1211.

7. Sokhna C, Cisse B, Ba eH, Milligan P, Hallett R, Sutherland C, Gaye O, Boulanger D, Simondon K, Targett G, Lines J, Greenwood B, Trape JF: A trial of the efficacy, safety and impact on drug resistance of four drug regimens for seasonal intermittent preventive treatment for malaria in Senegalese children. PLoS One 2008, 3:e1471.

8. Clarke SE, Jukes MC, Njagi JK, Khasakhala L, Cundill B, Otido J, Crudder C, Estambale BB, Brooker S: Effect of intermittent preventive treatment of malaria on health and education in schoolchildren: a clusterrandomised, double-blind, placebo-controlled trial. Lancet 2008, 372:127-138.

9. Dicko A, Sagara I, Sissoko MS, Guindo O, Diallo Al, Kone M, Toure OB, Sacko M, Doumbo OK: Impact of intermittent preventive treatment with sulphadoxine-pyrimethamine targeting the transmission season on the incidence of clinical malaria in children in Mali. Malar J 2008, 7:123.

10. Dicko A, Diallo Al, Tembine I, Dicko Y, Dara N, Sidibe Y, Santara G, Diawara H, Conaré T, Djimde A, Chandramohan D, Cousens S, Milligan PJ, Diallo DA, Doumbo OK, Greenwood B: Intermittent preventive treatment of malaria provides substantial protection against malaria in children already protected by an insecticide-treated bednet in Mali: a randomised, double-blind, placebo-controlled trial. PLOS Med 2011, 8: e1000407.

11. Konaté AT, Yaro JB, Ouédraogo AZ, Diarra A, Gansané A, Soulama I, Kangoyé DT, Kaboré Y, Ouédraogo E, Ouédraogo A, Tiono AB, Ouédraogo IN, Chandramohan D, Cousens S, Milligan PJ, Sirima SB, Greenwood B, Diallo DA: Intermittent preventive treatment of malaria provides substantial protection against malaria in children already protected by an insecticide-treated bednet in Burkina Faso: a randomised, double-blind, placebo-controlled trial. PLoS Med 2011, 8 : e1000408.

12. London School of Tropical Medicine and Hygiene: Drug Resistance Maps. [http://drugresistancemaps.org/].

13. Barnes KI, Little F, Smith PJ, Evans A, Watkins WM, White NJ: Sulfadoxinepyrimethamine pharmacokinetics in malaria: pediatric dosing implications. Clin Pharmacol Ther 2006, 80:582-596.

14. WHO/HTM/RBM/2003: Assessment and monitoring of antimalarial drug efficacy for the treatment of uncomplicated falciparum malaria.50. 2003, Ref Type: Report

15. Plowe CV, Djimde A, Wellems TE, Diop S, Kouriba B, Doumbo OK: Community pyrimethamine-sulfadoxine use and prevalence of resistant Plasmodium falciparum genotypes in Mali: a model for deterring resistance. Am J Trop Med Hyg 1996, 55:467-471.

16. Dolo A, Camara F, Poudiougo B, Toure A, Kouriba B, Bagayogo M, Sangaré $D$, Diallo M, Bosman A, Modiano D, Touré YT, Doumbo OK: [Epidemiology of malaria in a village of Sudanese savannah area in Mali (Bancoumana). 2. Entomo-parasitological and clinical study](in French). Bull Soc Pathol Exot 2003, 96:308-312.

17. Usp: Usp/Nf 2004 (United States Pharmacopeia 27/The National Formulary 22). United States Pharmacopeia 2003.

18. Minzi OM, Gupta A, Haule AF, Kagashe GA, Massele AY, Gustafsson LL: Lack of impact of artesunate on the disposition kinetics of sulfadoxine/ pyrimethamine when the two drugs are concomitantly administered. Eur J Clin Pharmacol 2007, 63:457-462.
19. White NJ, Stepniewska K, Barnes K, Price RN, Simpson J: Simplified antimalarial therapeutic monitoring: using the day-7 drug level? Trends Parasitol 2008, 24:159-163.

20. Mutabingwa TK, Maxwell CA, Sia IG, Msuya FH, Mkongewa S, Vannithone S, Curtis J, Curtis CF: A trial of proguanil-dapsone in comparison with sulfadoxine-pyrimethamine for the clearance of Plasmodium falciparum infections in Tanzania. Trans R Soc Trop Med Hyg 2001, 95:433-438.

21. Nankabirwa J, Cundill B, Clarke S, Kabatereine N, Rosenthal PJ, Dorsey G, Brooker S, Staedke SG: Efficacy, safety, and tolerability of three regimens for prevention of malaria: a randomized, placebo-controlled trial in Ugandan schoolchildren. PLoS One 2010, 5:e13438.

22. Some AF, Sere YY, Dokomajilar C, Zongo I, Rouamba N, Greenhouse B, Ouédraogo JB, Rosenthal PJ: Selection of known Plasmodium falciparum resistance-mediating polymorphisms by artemether-lumefantrine and amodiaquine-sulfadoxine-pyrimethamine but not dihydroartemisininpiperaquine in Burkina Faso. Antimicrob Agents Chemother 2010, 54:1949-1954.

23. Faye B, Ndiaye JL, Ndiaye D, Dieng Y, Faye O, Gaye O: Efficacy and tolerability of four antimalarial combinations in the treatment of uncomplicated Plasmodium falciparum malaria in Senegal. Malar J 2007, 6:80.

24. Tagbor H, Bruce J, Browne E, Randal A, Greenwood B, Chandramohan D: Efficacy, safety, and tolerability of amodiaquine plus sulphadoxinepyrimethamine used alone or in combination for malaria treatment in pregnancy: a randomised trial. Lancet 2006, 368:1349-1356.

25. Tekete $M$, Djimde AA, Beavogui AH, Maiga $H$, Sagara I, Fofana B, Ouologuem D, Dama S, Kone A, Dembele D, Wele M, Dicko A, Doumbo OK: Efficacy of chloroquine, amodiaquine and sulphadoxinepyrimethamine for the treatment of uncomplicated falciparum malaria: revisiting molecular markers in an area of emerging $A Q$ and SP resistance in Mali. Malar J 2009, 8:34

26. Djimde AA, Fofana B, Sagara I, Sidibe B, Toure S, Dembele D, Dama S, Ouologuem D, Dicko A, Doumbo OK: Efficacy, safety, and selection of molecular markers of drug resistance by two ACTs in Mali. Am J Trop Med Hyg 2008, 78:455-461.

27. Aubouy A, Bakary M, Keundjian A, Mbomat B, Makita JR, Migot-Nabias F, Cot M, Le Bras J, Deloron P: Combination of drug level measurement and parasite genotyping data for improved assessment of amodiaquine and sulfadoxine-pyrimethamine efficacies in treating Plasmodium falciparum malaria in Gabonese children. Antimicrob Agents Chemother 2003, 47:231-237.

28. Bell DJ, Nyirongo SK, Mukaka M, Molyneux ME, Winstanley PA, Ward SA: Population pharmacokinetics of sulfadoxine and pyrimethamine in Malawian children with malaria. Clin Pharmacol Ther 2011, 89:268-275, Epub 2010 Dec 29.

\section{doi:10.1186/1475-2875-10-275}

Cite this article as: Tekete et al:: Effects of amodiaquine and artesunate on sulphadoxine-pyrimethamine pharmacokinetic parameters in children under five in Mali. Malaria Journal 2011 10:275

\section{Submit your next manuscript to BioMed Central and take full advantage of:}

- Convenient online submission

- Thorough peer review

- No space constraints or color figure charges

- Immediate publication on acceptance

- Inclusion in PubMed, CAS, Scopus and Google Scholar

- Research which is freely available for redistribution

Submit your manuscript at www.biomedcentral.com/submit
C Biomed Central 